\title{
Scanning Electron Microscopy Analysis of RinsEndo System and Conventional Irrigation for Debris Removal
}

\author{
Rodrigo Ricci VIVAN ${ }^{1}$ \\ Melina Vieira BORTOLO ${ }^{2}$ \\ Marco Antonio Hungaro DUARTE ${ }^{2}$ \\ Ivaldo Gomes de MORAES $^{2}$ \\ Mario TANOMARU-FILHO ${ }^{1}$ \\ Clovis Monteiro BRAMANTE ${ }^{2}$ \\ ${ }^{1}$ Department of Restorative Dentistry, Araraquara Dental School, São Paulo State University, Araraquara, SP, Brazil \\ ${ }^{2}$ Department of Endodontics, Bauru Dental School, University of São Paulo, Bauru, SP, Brazil

\begin{abstract}
A new device for irrigation, which presents hydrodynamic activation based on the pressure-suction technology, has recently been introduced to the market: the RinsEndo system. This study compared the efficacy of the RinsEndo system and conventional (manualdynamic) irrigation in the removal of debris from the root canal walls, using scanning electron microscopy (SEM). Twenty mandibular premolars with completely formed roots were selected and randomly divided into group 1 (irrigation with the RinsEndo system) and group 2 (conventional irrigation). The canals were irrigated with $1 \mathrm{~mL}$ of saline at each change of instrument. Instrumentation started with a $\# 15 \mathrm{~K}$ file and continued up to a $\# 40 \mathrm{~K}$ file, which was standardized as the working length instrument. Then, the teeth were sectioned in buccolingual direction and the halves were sputter-coated with gold and examined by SEM. The apical, middle and cervical root canal thirds were evaluated, and the results were analyzed statistically by the Mann-Whitney test for comparison between methods, Kruskal-Wallis test for comparison among thirds, and Miller test for individual comparisons. A significance level of $5 \%$ was set for all analyses. The results did not show significant differences $(p>0.05)$ between methods at each third and among thirds for each technique analyzed individually. In conclusion, there was no difference in the cleaning ability of the RinsEndo system and conventional irrigation.
\end{abstract}

Key Words: RinsEndo system, irrigation, endodontics.

\section{INTRODUCTION}

The success of endodontic treatment depends on some factors, such as correct indication, accurate diagnosis, adequate cleaning and root canal preparation, quality of root canal filling, and an adequate final restoration. All these factors are interdependent and equally important. The persistence of pulp remnants, microorganisms and bacterial byproducts may lead to treatment failure (1). Their elimination may be achieved by the mechanical action of instruments on the root canal walls and the chemical and physical action of irrigants (2).

The complexity of the root canal system may hinder the action of endodontic instruments $(3,4)$ and, in these cases, irrigation is an important adjuvant for cleaning physically and chemically areas that are not reached by the instruments (5-10).

The cleaning provided by irrigants is related to the depth of penetration of the irrigation needle in the root canal, pressure applied, solution flow and others (7). Several studies have evaluated the efficacy of instruments, methods and cleaning techniques on the root canal system (11-13). Recently, A new device for irrigation, which presents hydrodynamic activation based on the pressure-suction technology, has recently been introduced to the market: the RinsEndo system.

Hauser et al. (14) evaluated the efficacy of the

Correspondence: Dr. Rodrigo Ricci Vivan, Departamento de Odontologia Restauradora, Faculdade de Odontologia de Araraquara, UNESP, Rua Humaitá, 1680, 331, 14801-903 Araraquara, SP, Brasil. Tel: +55-14-3234-6147. e-mail: rodrigovivan@yahoo.com.br 
RinsEndo system compared to the conventional method for root canal cleaning, using a labeling solution. The authors concluded that the RinsEndo system was more effective than conventional irrigation as to the capacity of penetration in the dentin tubules. McGill et al. (15) compared ex vivo the efficacy of three irrigation protocols using a collagen tincture applied to the root canal walls, concluding that the RinsEndo system was significantly more effective than static irrigation, yet was it was not more effective than the manual-dynamic irrigation. In addition, the efficacy was greater when the cannula was placed closer to the working length (WL). However, those studies used irrigant solutions with chemical activity against the smear layer and debris. The use of EDTA or sodium hypochlorite $(\mathrm{NaOCl})$ can be a confounding factor because it is not clear whether the cleaning ability is improved by the new irrigation methods or by the chemical activity of the irrigants used.

The efficacy of this new system on debris removal during root canal instrumentation has not yet been evaluated. This study compared the efficacy of the RinsEndo system and conventional (manual-dynamic) irrigation for debris removal from canal walls by scanning electron microscopy (SEM).

\section{MATERIAL AND METHODS}

The study was conducted on 20 mandibular premolars with completely formed roots and a single root canal extracted due to orthodontic reasons. The teeth had similar canal diameters as shown by previous periapical radiographic examination (16). Coronal opening was performed in a standardized manner, using diamond burs $1014 \mathrm{HL}$ and 3082 at high-speed under refrigeration. After opening, a \#15 K file (Dentsply/ Maillefer, Ballaigues, Switzerland) with a rubber stop was introduced in the canal until its tip could be seen through the apical foramen. The tooth length was then checked and $1 \mathrm{~mm}$ was subtracted to determine the WL.

The teeth were randomly divided into 2 groups of 10 teeth each, according to the irrigation method employed. In group 1, the root canals were irrigated with the RinsEndo system (Dürr Dental GmbH \& Co. KG, Bietigheim-Bissingen, Germany) connected to a $30 \mathrm{G}$ needle (Dürr Dental GmbH \& Co. KG) supplied with the system. This needle presents a $7-\mathrm{mm}$ opening on the lateral aspect. The technology of this system is based on pressure-suction with hydrodynamic activation. The system also has a plastic cover that is connected to the irrigation needle, to avoid reflux of irrigant on the patient or the professional. The system presents an opening for insertion of the suction needle during irrigation and suction procedures. In group 2, the root canals were irrigated with a conventional syringe (Ultradent, South Jordan, UT, USA) with $30 \mathrm{G}$ irrigation needle Navitip (Ultradent) (manual-dynamic) irrigation.

For both groups, instrumentation was done with hand files according to a step-back technique, starting with a \#20 K-file up to \#40 K file (WL instrument), followed by stepback preparation up to a \#55 K-file, decreasing the length in $1 \mathrm{~mm}$ at each change to a greater instrument. At each change of instrument, irrigation was performed with $2 \mathrm{~mL}$ of saline. In group 1, the needle was placed on the root canal opening and the system was turned on for $7 \mathrm{~s}$, which corresponds to the use of $2 \mathrm{~mL}$ of saline. In group 2, the needle was inserted at 3 $\mathrm{mm}$ short of the WL with back and forth movements.

After instrumentation, the teeth were sectioned in buccolingual direction with carborundum discs at low speed. The most representative halves of each tooth were selected, sputter-coated and analyzed by SEM. Each specimen was photographed at the apical, middle and cervical thirds, and 3 calibrated examiners assigned scores to the SEM micrographs according to the amount of debris present on the root canal walls, as follows: score 1: absence debris; score 2: smear layer obliterating the dentin tubules; score 3: smear layer covering the dentin walls; score 4: debris covering the dentin walls (Fig. 1). The study had a double-blind design.

Coincident scores between 2 or more examiners were assigned to the specimen. In case of disagreement among the 3 examiners, the specimen was reevaluated. The scores were analyzed statistically by the MannWhitney U-test for comparison between techniques at each third, Kruskal Wallis test for overall comparison between thirds, and Miller test for individual comparisons, at a significance level of $p<0.05$. The Kendall test was also applied for analysis of interexaminer agreement.

\section{RESULTS}

Table 1 shows the scores attributed to each specimen, at each third, according to the techniques. Table 2 shows the medium posts of the scores of each third in each group, obtained by the Kruska Wallis test. Figures 2 and 3 show representative samples at the apical (A), middle (B) and cervical (C) thirds of the Rins Endo and conventional groups, respectively. 

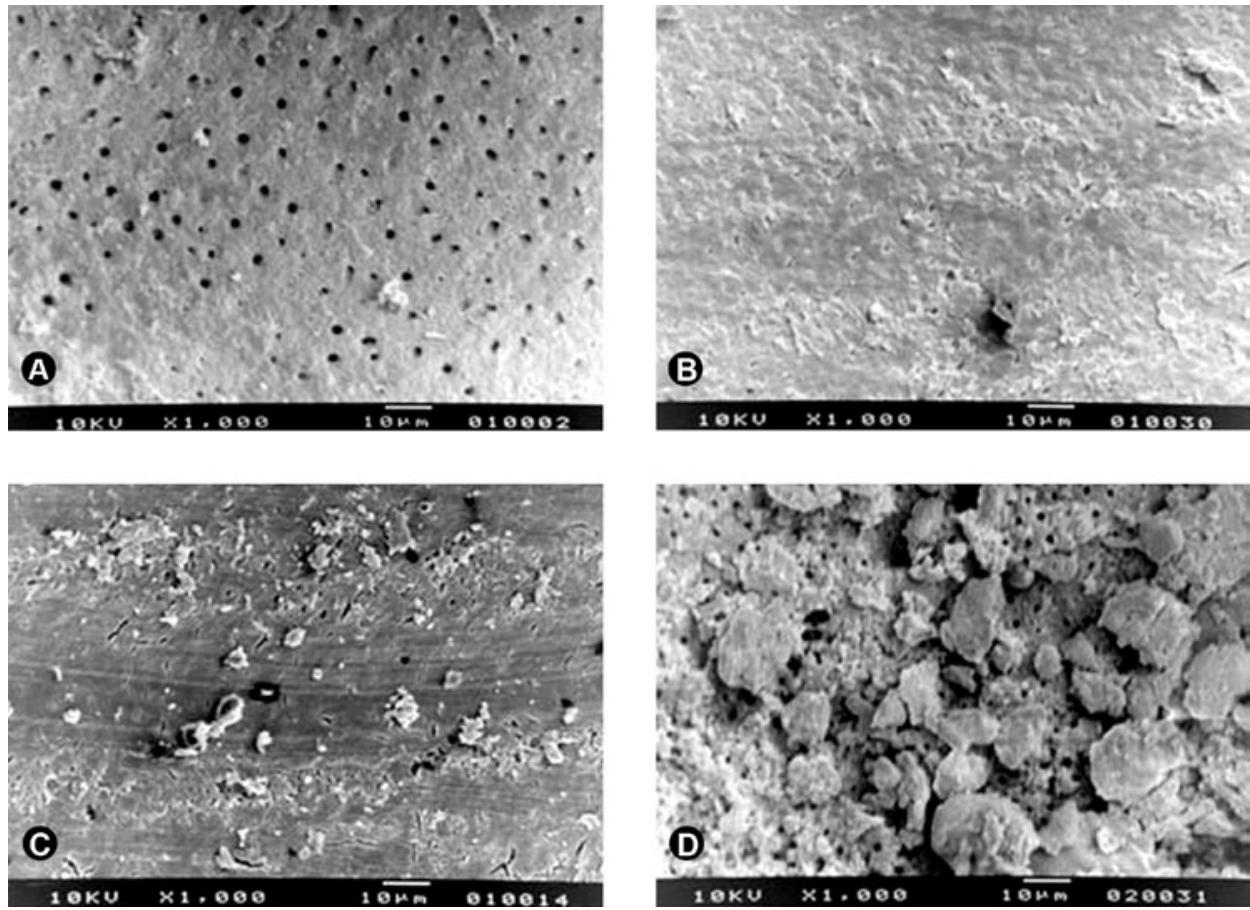

Figure 1. Scores used to evaluate the groups. Score $1=$ absence of debris and smear layer; Score $2=$ smear layer obliterating the dentin tubules; Score 3 = smear layer covering the dentin walls; Score $4=$ debris covering the dentin walls $(1000 \times$ magnification).

Table 1. Scores attributed to each specimen at each root canal third, according to the irrigation techniques employed.

\begin{tabular}{|c|c|c|c|c|c|c|}
\hline \multirow{2}{*}{ SP } & \multicolumn{3}{|c|}{$\begin{array}{l}\text { RinsEndo system } \\
\text { (Group 1) }\end{array}$} & \multicolumn{3}{|c|}{$\begin{array}{c}\text { Conventional irrigation } \\
\text { (Group 2) }\end{array}$} \\
\hline & AP & $\mathrm{MD}$ & $\mathrm{CV}$ & $\mathrm{AP}$ & MD & $\mathrm{CV}$ \\
\hline 1 & 4 & 1 & 2 & 4 & 4 & 4 \\
\hline 2 & 1 & 2 & 2 & 4 & 3 & 2 \\
\hline 3 & 3 & 2 & 2 & 4 & 2 & 4 \\
\hline 4 & 3 & 3 & 3 & 3 & 2 & 3 \\
\hline 5 & 3 & 3 & 3 & 2 & 3 & 2 \\
\hline 6 & 2 & 3 & 3 & 4 & 3 & 3 \\
\hline 7 & 3 & 4 & 2 & 4 & 4 & 2 \\
\hline 8 & 2 & 2 & 1 & 2 & 2 & 4 \\
\hline 9 & 3 & 2 & 2 & 2 & 2 & 2 \\
\hline 10 & 3 & 3 & 2 & 4 & 3 & 4 \\
\hline
\end{tabular}

$\mathrm{SP}=$ specimen; $\mathrm{AP}=$ apical third $\mathrm{MD}=$ middle third $\mathrm{CV}=$ cervical third; Score $1=$ absence of debris and smear layer on the dentin walls; Score 2 = smear layer obliterating the dentin tubules; Score 3 = smear layer covering the dentin walls; Score $4=$ debris covering the dentin walls.
There were no significant differences $(\mathrm{p}>0.05)$ between the irrigation techniques for any third. There were no significant differences among the thirds for either type of irrigation $(\mathrm{p}>0.05)$. There was significant agreement $(\mathrm{p}<0.05)$ between the scores assigned by the examiners (Kendall coefficient $=0.798761 ; \mathrm{p}<0.05$ ).

\section{DISCUSSION}

One of the most important goals of root canal instrumentation is the removal of pulp remnants and microorganisms and their toxins from the root canal system (1). This study compared the efficacy of the

Table 2. Medium posts of the scores of each third in each group, obtained by the Kruska Wallis test.

\begin{tabular}{lcc}
\hline Root canal third & $\begin{array}{c}\text { RinsEndo } \\
\text { system }\end{array}$ & $\begin{array}{c}\text { Conventional } \\
\text { irrigation }\end{array}$ \\
\hline Apical & 8.6 & 12.4 \\
Middle & 9.6 & 11.4 \\
Cervical & 8.2 & 12.8 \\
\hline
\end{tabular}


RinsEndo system and the conventional irrigation on debris removal from the root canal walls, by SEM. The method is reliable, as previously described (17-19). SEM analysis is useful to evaluate the action of different instrumentation and irrigation system on the root canal walls. Although the RinsEndo system manufacturer suggests the use of $\mathrm{NaOCl}$, we aimed at evaluating the physical action of the irrigation, and not the chemical action of the irrigant (20). Therefore, saline was the irrigant of choice, different from other studies that evaluated new irrigation systems using $\mathrm{NaOCl}$ at $5.25 \%$ (11-13), 2.5\% (15) and 2\% (14).

The present results demonstrated that the
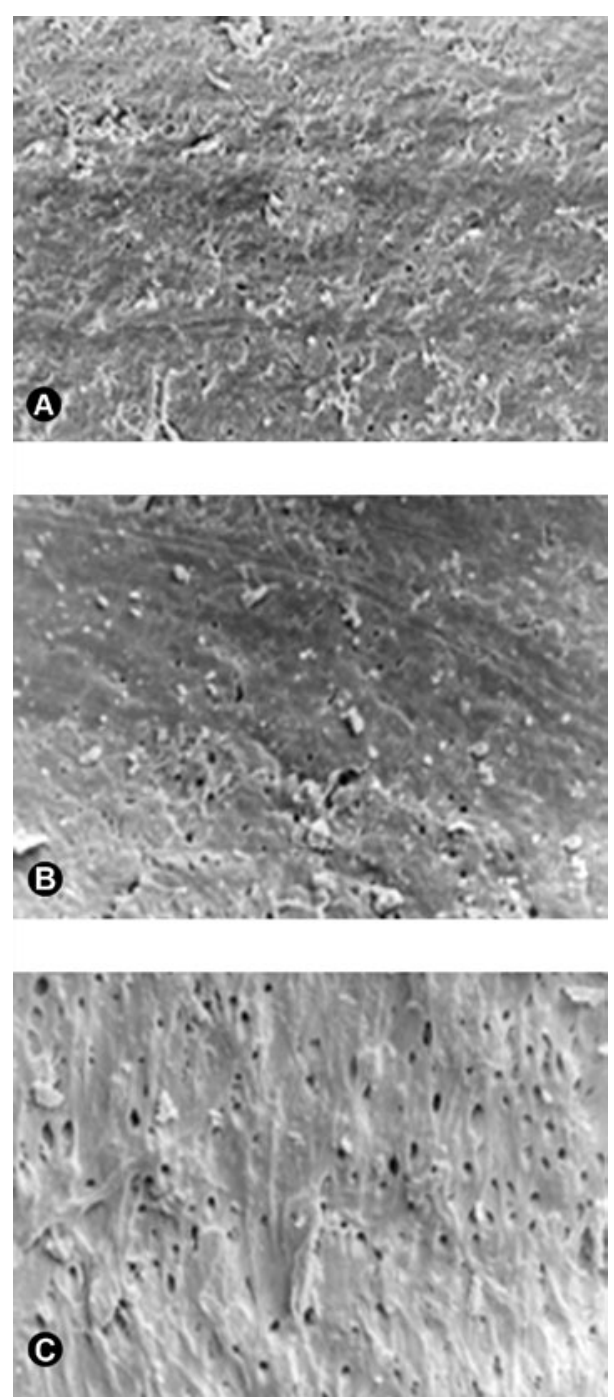

Figure 2. Representative samples of RinsEndo system. A $=$ apical third; $\mathrm{B}=$ middle third; $\mathrm{C}=$ cervical third $(1000 \times$ magnification).
RinsEndo system was not more effective than conventional irrigation. Similar studies using other systems for root canal irrigation were also conducted with the same goal. Al-Hadlaq et al. (12) used SEM to evaluate the ability of NaviTip FX and NaviTip systems for cleaning the cervical, middle and apical thirds of root canals, and found that the NaviTip FX had significantly better outcomes only at the cervical third. Nielsen and Baumgartner (13) compared the EndoVac system and the conventional needle for smear layer removal, both acting at 1 and $3 \mathrm{~mm}$ from the WL, and reported significant difference between thirds only at $1 \mathrm{~mm}$ from the WL, with better results for EndoVac. With the same purpose,
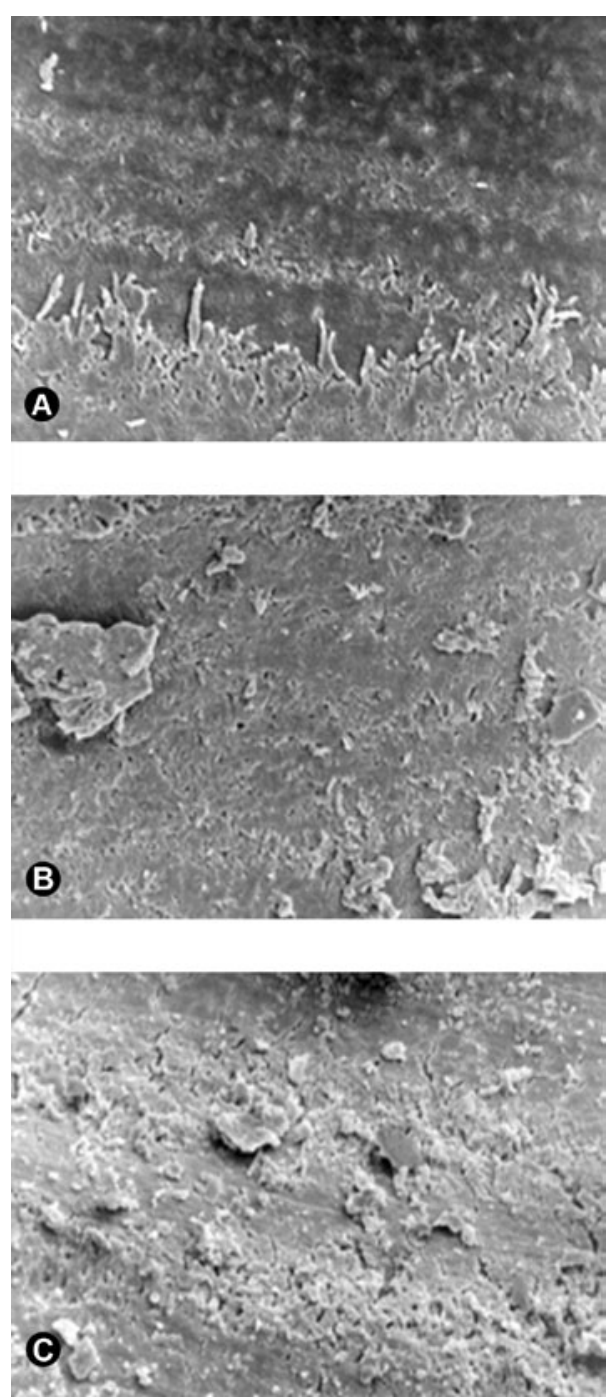

Figure 3. Representative samples of conventional syringe. $\mathrm{A}=$ apical third; $\mathrm{B}=$ middle third; $\mathrm{C}=$ cervical third $(1000 \times$ magnification). 
the Quantec-E system was compared to conventional irrigation, being more effective only at the cervical third.

The RinsEndo system, compared to static and conventional manual irrigation, showed better ability of penetration of the irrigant in the dentin tubules. Due to the greater ability of penetration, the system was believed to be more effective for cleaning of the root canal walls compared to the conventional irrigation. However, in the present study, no significant difference was found between techniques at any canal third. These findings are different from those of McGill et al. (15), who found that automated-dynamic irrigation with the RinsEndo system was significantly less effective than conventional manual-dynamic irrigation, on removal of the collagen biomolecular film in an ex vivo. Accordingly, Hauser et al. (14) found that the hydrodynamic rinsing demonstrated an improvement over conventional methods in terms of dentine penetration of a dye marker,

In conclusion, there was no difference between the RinsEndo system and conventional irrigation in the cleaning ability of root canal walls. No differences were found among the canal thirds regarding debris removal.

\section{RESUMO}

Um novo método para irrigação, que apresenta ativação hidrodinâmica baseado na tecnologia de pressão e aspiração, foi recentemente introduzido no mercado: o sistema RinsEndo. O presente estudo comparou a eficácia do sistema RinsEndo e irrigação convencional(manual-dinâmica) na remoção de debris do canal radicular, empregando-se microscopia eletrônica de varredura (MEV). Vinte pré-molares inferiores com raiz completamente formada foram selecionados e divididos aleatoriamente em grupo 1 (sistema RinsEndo) e grupo 2 (irrigação convencional). Os canais foram irrigados com $1 \mathrm{~mL}$ de solução salina a cada troca de instrumento. A instrumentação foi iniciada com uma lima tipo K \#15 dilatando-se até lima tipo K \#40, no comprimento de trabalho. Posteriormente os dentes foram clivados no sentido vestíbulo-lingual e as hemisecções foram metalizadas com ouro e analisadas em MEV. Os terços cervical, médio e apical foram avaliados, e os resultados foram analisados estatisticamente pelo teste de Mann-Whitney para comparação entre métodos, e o teste Kruskal-Wallis para comparação entre terços e o teste de Miller para os confrontos individuais. Foi empregado o nível de significância de 5\% para todas as análises. Os resultados não mostraram diferença estatisticamente significante $(\mathrm{p}>0,05)$ entre métodos em cada terço, nem entre terços para cada técnica analisada individualmente. Concluiu-se que não houve diferença na capacidade de limpeza do sistema RinsEndo e da irrigação convencional.

\section{REFERENCES}

1. Gutmann JL. Clinical, radiographic, and histologic perspectives on success and failure in endodontics. Dent Clin North Am 1992;36:379-392.

2. Schilder H. Cleaning and shaping the root canal. Dent Clin North Am 1974;18:269-296.

3. Davis SR, Brayton SM, Goldman M. The morphology of the prepared root canal: a study utilizing injectable silicone. Oral Surg Oral Med Oral Pathol 1972;34:642-648.

4. Mizrahi SJ, Tucker JW, Seltzer S. A scanning electron microscopic study of the efficacy of various endodontic instruments. J Endod 1975;1:324-333.

5. Stewart GG. Importance of chemomechanical preparation of the root canal. Oral Surg Oral Med Oral Pathol 1955;8:993-999.

6. Gutierrez JH, Garcia J. Microscopic and macroscopic investigation on results of mechanical preparation of root canals. Oral Surg Oral Med Oral Pathol 1968;25:108-116.

7. Chow TW. Mechanical effectiveness of root canal irrigation. J Endod 1983;9:475-479.

8. Estrela C, Estrela CR, Barbin EL, Spanó JC, Marchesan MA, Pécora JD. Mechanism of action of sodium hypochlorite. Braz Dent J 2002;13:113-117.

9. Ferraz CC, Gomes BP, Zaia AA, Teixeira FB, Souza-Filho FJ. Comparative study of the antimicrobial efficacy of chlorhexidine gel, chlorhexidine solution and sodium hypochlorite as endodontic irrigants. Braz Dent J 2007;18:294-298.

10. Silva LA, Leonardo MR, Assed S, Tanomaru Filho M. Histological study of the effect of some irrigating solutions on bacterial endotoxin in dogs. Braz Dent J 2004;15:109-114.

11. Setlock J, Fayad MI, BeGole E, Bruzick M. Evaluation of canal cleanliness and smear layer removal after the use of the Quantec-E irrigation system and syringe: a comparative scanning electron microscope study. Oral Surg Oral Med Oral Pathol Oral Radiol Endod 2003;96:614-617.

12. Al-Hadlaq SM, Al-Turaiki SA, Al-Sulami U, Saad AY. Efficacy of a new brush-covered irrigation needle in removing roo canal debris: a scanning electron microscopic study. J Endod 2006;32:1181-1184.

13. Nielsen BA, Baumgartner JC. Comparison of the EndoVac system to needle irrigation of root canals. J Endod 2007;33:611-615.

14. Hauser V, Braun A, Frentzen M. Penetration depth of a dye marker into dentine using a novel hydrodynamic system (RinsEndo). Int Endod J 2007;40:644-652.

15. McGill S, Gulabivala K, Mordan N, Ng YL. The efficacy of dynamic irrigation using a commercially available system (RinsEndo) determined by removal of a collagen "bio-molecular film" from an ex vivo model. Int Endod J 2008;41:602-608.

16. Kennedy WA, Walker WA 3rd, Gough RW. Smear layer removal effects on apical leakage. J Endod 1986;12:21 2717. McComb D, Smith DC. A preliminary scanning electron microscopic study of root canals after endodontic procedures. J Endod 1975;1:238-242.

18. Baker NA, Eleazer PD, Averbach RE, Seltzer S. Scanning electron microscopic study of the efficacy of various irrigating solutions. J Endod 1975;1:127-135.

19. Bolanos OR, Jensen JR. Scanning electron microscope comparisons of the efficacy of various methods of root canal preparation. J Endod 1980;6:815-822.

20. Marques AA, Marchesan MA, Sousa-Filho CB, Silva-Sousa YT, Sousa-Neto MD, Cruz-Filho AM. Smear layer removal and chelated calcium ion quantification of three irrigating solutions. Braz Dent J 2006;17:306-309.

Accepted September 9, 2010 